\title{
An Analysis on the Inpatients Level of Satisfaction in Malahayati Islamic Hospital
}

\author{
Zahara Meutia* Harmein Nasution Zahari Zen \\ Program Study of Magister Management, University of Sumatera Utara, Indonesia \\ Jl. Prof. T. Maas, Kampus USU, Medan, 20155
}

\begin{abstract}
Malahayati Islamic Hospital Medan is a Private General Hospital type C with excellent service of cardiac catheterization lab. Based on data obtained from Malahayati Islamic Hospital Medan, it is seen that the number of inpatients and the value of Bed Occupancy Rate (BOR) at Rumah Sakit X Medan decreased in 2015 and 2016.The purpose of this research is to analyze patient satisfaction of inpatient of Rumah Sakit X Medan and to get effective policy formula to increase patient satisfaction of inpatient of Rumah Sakit X Medan. This type of research is survey research. Interviews with questionnaires were conducted to 41 patients who were undergoing treatment at the inpatient installation of Rumah Sakit X Medan with the criteria of patients who had undergone treatment for more than 2 (two) days with purposive sampling method. Data analysis used descriptive statistical analysis model and Cartesian diagram.From the analysis, it was found that the suitability level was $90.62 \%$, which means that the patient was not satisfied with Rumah Sakit X service. Variables that must be improved in quadrant I is the service of patient acceptance, medical facilities and medicine, hospital physical condition and treatment room, and hospital outbreak service.
\end{abstract}

Keywords: Cartesian Diagram; Hospitalization; Patient Satisfaction

DOI: $10.7176 / \mathrm{EJBM} / 11-12-03$

Publication date: April $30^{\text {th }} 2019$

\section{Introduction}

Meeting customer needs and expectations for the quality of hospital services is a big challenge for hospitals to survive in this industry. Service is one business that can be used as a basis for making a difference with other hospitals. The form of service performed by a hospital is different from other hospitals. Every hospital is trying to attract consumehospital to become loyal customehospital. Hospitals as provide hospital of health services must be able to provide quality services as one of the hospital's efforts to maintain existence and improve competitive position. The creation of service quality will certainly create satisfaction with service use hospital.

Hospital must focus on providing quality services to patients in accordance with existing standards. The quality of hospital services is very important so that every hospital must try to maintain and improve the quality of its services. Improving the quality of services is needed to improve patient satisfaction and the image of the hospital so that hospital expectations will be achieved by becoming the best health care provider for patients.

Table 1. Data Number of Inpatients Malahayati Islamic Hospital

\begin{tabular}{llllll}
\hline & $\mathbf{2 0 1 2}$ & $\mathbf{2 0 1 3}$ & $\mathbf{2 0 1 4}$ & $\mathbf{2 0 1 5}$ & $\mathbf{2 0 1 6}$ \\
\hline Patient & 4863 & 5091 & 7753 & 7216 & 6777 \\
BOR & $79.50 \%$ & $67.50 \%$ & $70.72 \%$ & $56.30 \%$ & $57.02 \%$ \\
\hline
\end{tabular}

Source : Medical Record Malahayati Islamic Hospital

Based on the results of data obtained from the medical record of RSI Malahayati data on the number of hospitalized patients and Bed Ocuppancy Rate (BOR) data RSI Malahayati show degradation. The data obtained, from 2011 to 2016 showed a decrease in the number of patients in 2015 and 2016. The degradation also occurred in the 2015 BOR value with a value of $56.30 \%$ not reaching the ideal BOR parameter value.

The satisfaction survey of inpatient patients at Malahayati Hospital in March 2016 showed an index of patient satisfaction of $83.3 \%$ and has not reached the Hospital Service Standard, which is equal to $\geq 90 \%$. Hospitals as providers of health services must be able to anticipate this because a patient who is dissatisfied can damage the image of the hospital, decrease in the number of visitors and ultimately reduce hospital profits. Hospital must have a way to minimize the number of patients who are not satisfied after the process of using services occurs.

\section{Literature Review}

Inpatient services are a group of health services in hospitals that are a combination of several service functions. The category of patients admitted to hospitalization are patients who need intensive care or close observation because of the disease.

Service quality is related to the ability of an organization to meet or exceed customer expectations (Payne, 2007). The dimensions of service quality must be mixed well. If not, this can lead a gap between the company and the customer, because of their different perceptions of the form of service. Hospitals must act wisely by measuring 
customer satisfaction regularly because one of the keys to maintaining customers is customer satisfaction. Basically customer satisfaction and dissatisfaction with the service will affect the next behavior pattern. If the customer is satisfied, he will show the possibility of returning. Satisfied customers also tend to provide good references to service products to others.

Customer surveys are a commonly used way of measuring customer satisfaction, for example, by postal mail, telephone, or direct interview. Through surveys, companies will get responses and feedback directly from customers and give a positive sign that the company is paying attention to customers

Utama (2005) states the priority of quality indicators of health services according to patients is a major aspect that becomes an important guideline or measure of guidelines, should be related to the organization of hospital health services that are part of the experience or perceived hospital patients. Health service indicators selected by patients as a priority measure of the quality of health services, tend to be the main source of patient satisfaction.

According to Herlambang (2016), several indicators of patient satisfaction in hospitals are indicators of service quality in hospital, namely:

1. Hospital admission services

2. Doctor services

3. Nurse services

4. Patient nutrition services

5. Medical and medicinal facilities

6. Condition of hospital facilities (hospital physical)

7. Condition of treatment room facilities

8. Administrative service

\section{Patient Satisfaction Level :}

1. Admissions Services,

2. Doctor Services,

3. Nurse Services,

4. Food Services And Menu

5. Medical Facilities And Medicines,

6. Physical Conditions And Care Rooms, 7. Administrative Services.

Figure 1: Conseptual Framework

\section{Research Methods}

The method of this research is survey research. Population was all hospitalized patients at Malahayati Islamic Hospital. Sampling uses purposive sampling, data is collected through interviews, questionnaires and documentation studiesThe number of samples that can be reached by researchers for one month is 41 people. Data were analyzed using descriptive statistical analysis and Cartesian diagram.

\section{Results}

\section{Performance Level Analysis}

The doctor's service variable has the highest average value (4.5) compared to other services, meaning that the highest level of performance is found in the doctor's service. While the highest score is an indicator of doctor's attitude and behavior (score 4.59 or very good). Administrative services out of hospital variables have the lowest average value, namely (4.06) meaning that the level of performance in this service is the lowest compared to other services. On the other hand, the lowest performance rating is an insect-free treatment room indicator (score 3.83 or good)

\section{Importance Level Analysis}

Doctor service variables have the highest average value (4.8) compared to other services, meaning that the highest level of importance is found in the service. Food service and menu variables that have the lowest average value are (4.60), meaning that the lowest level of importance is found in the service, so that patients feel that these attributes do not affect the ongoing service.

\section{Conformity Level Analysis}

The level of conformity is the result of the comparison score performance with a score of interests. This level of conformity will determine the priority order of increasing factors that affect patient satisfaction. Based on both scoring scores, the overall fitness level is $90.62 \%$. This means that Malahayati Hospital has fulfilled patient expectations of $90.62 \%$ and $9.38 \%$ of patient expectations have not been fulfilled. The level of conformity of the 42 service indicators, there is one indicator that is in accordance with the patient's interests, the attitudes and behavior of the doctor at the time of examination and the indicator with the lowest level of compliance is the free insect room 


\section{Cartesian Diagram}

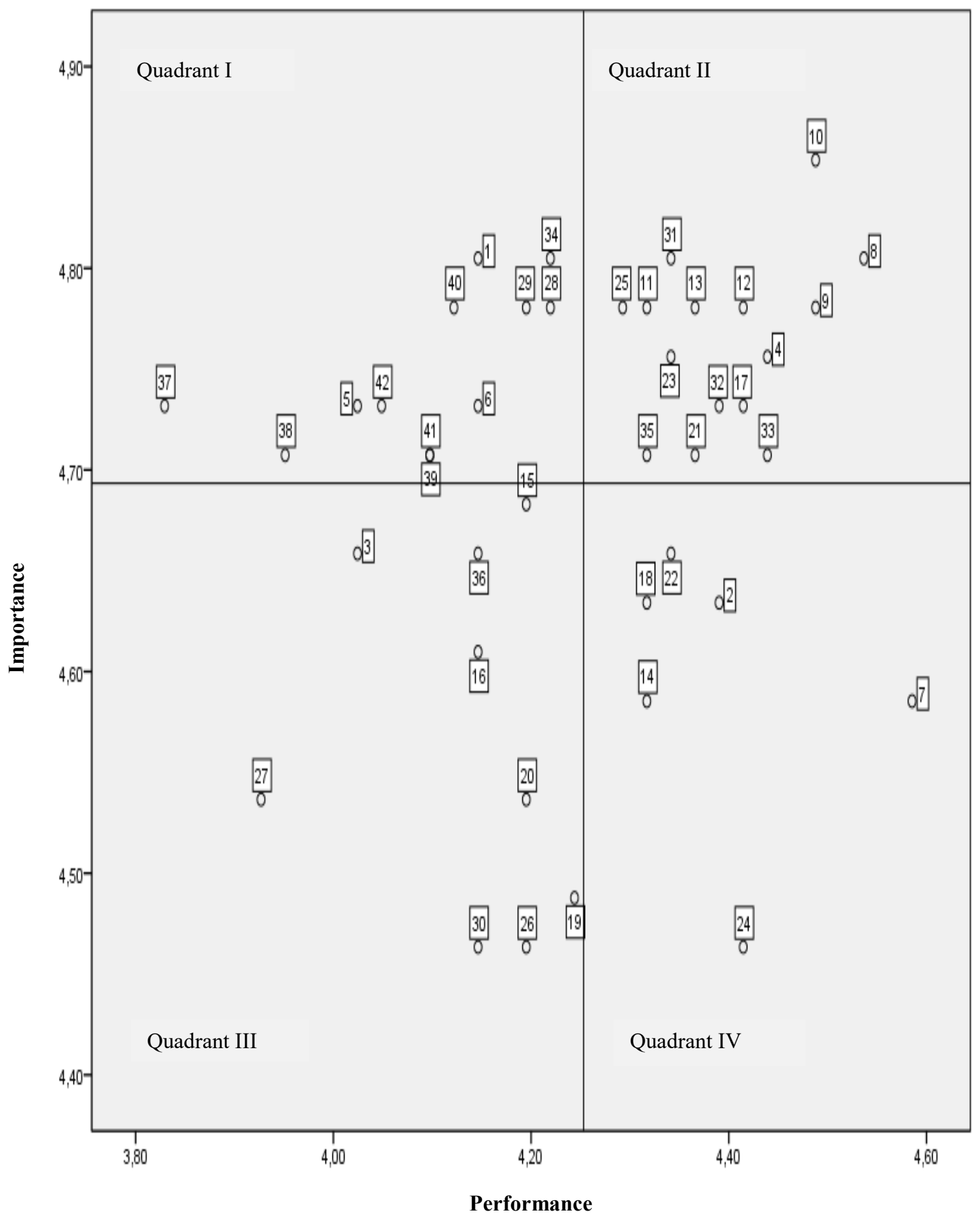

Figure 2 Cartesian Diagram 
Tabel 2 The Mean Value of Level of Importance and Level Satisfaction

\begin{tabular}{|c|c|c|c|c|c|}
\hline No & Quadrant & $\begin{array}{l}\text { Atribut } \\
\text { Code }\end{array}$ & Atribut description & $\begin{array}{l}\text { Mean } \\
\text { performance } \\
\text { rating }\end{array}$ & $\begin{array}{l}\text { Mean } \\
\text { importance } \\
\text { rating }\end{array}$ \\
\hline 1 & \multirow{12}{*}{ Quadrant 1} & 1 & $\begin{array}{l}\text { Service before being sent to the treatment room } \\
\text { very quickly (Admission Service) }\end{array}$ & 4.15 & 4.8 \\
\hline 2 & & 5 & $\begin{array}{l}\text { Duration of service in the emergency room } \\
\text { (Admission Service) }\end{array}$ & 4.02 & 4.73 \\
\hline 3 & & 6 & $\begin{array}{l}\text { Emergency room has very complete equipment } \\
\text { (Admission Service) }\end{array}$ & 4.15 & 4.73 \\
\hline 4 & & 26 & $\begin{array}{l}\text { Medical equipment in hospitals (medical } \\
\text { facilities and medicines) }\end{array}$ & 4.2 & 4.46 \\
\hline 5 & & 29 & $\begin{array}{l}\text { Hospital laboratory services (medical facilities } \\
\text { and medicines) }\end{array}$ & 4.2 & 4.78 \\
\hline 6 & & 34 & $\begin{array}{l}\text { The physical condition of the treatment room is } \\
\text { neat, clean and comfortable (Physical Condition } \\
\text { and treatment room) }\end{array}$ & 4.22 & 4.8 \\
\hline 7 & & 37 & $\begin{array}{l}\text { Insect-free treatment room (ants, flies, } \\
\text { mosquitoes) } \\
\text { room) }\end{array}$ & 3.83 & 4.73 \\
\hline 8 & & 38 & $\begin{array}{l}\begin{array}{l}\text { Administrative services } \\
\text { (administrative services) }\end{array} \\
\end{array}$ & 3.95 & 4.71 \\
\hline 9 & & 39 & $\begin{array}{l}\text { Financial regulations before entering the } \\
\text { treatment room are very clear (Administration } \\
\text { Services) }\end{array}$ & 4.1 & 4.71 \\
\hline 10 & & 40 & $\begin{array}{l}\text { How to pay for the maintenance fee } \\
\text { (administrative services) }\end{array}$ & 4.12 & 4.78 \\
\hline 11 & & 41 & $\begin{array}{l}\text { When completing administration of care costs } \\
\text { (administrative services) }\end{array}$ & 4.1 & 4.71 \\
\hline 12 & & 42 & $\begin{array}{llcr}\text { Attitudes and } & \begin{array}{l}\text { behavior } \\
\text { of }\end{array} & \text { financial } \\
\text { administration } & \text { officers } & \text { (Administration } \\
\text { Services) } & & \\
\end{array}$ & 4.05 & 4.73 \\
\hline 13 & \multirow{12}{*}{ Quadrant 2} & 4 & $\begin{array}{l}\text { The services of the Emergency room officers are } \\
\text { very good (Admission Service) }\end{array}$ & 4.44 & 4.76 \\
\hline 14 & & 8 & $\begin{array}{l}\text { A doctor's explanation when taking action is very } \\
\text { clear (Doctor's Service) }\end{array}$ & 4.54 & 4.8 \\
\hline 15 & & 9 & $\begin{array}{l}\text { The doctor's knowledge and competence are very } \\
\text { good (Doctor's Service) }\end{array}$ & 4.49 & 4.78 \\
\hline 16 & & 10 & $\begin{array}{l}\text { Doctors are very serious in dealing with patient } \\
\text { diseases (Doctor Services) }\end{array}$ & 4.49 & 4.85 \\
\hline 17 & & 11 & $\begin{array}{l}\text { Doctors give medicines very effective (Doctor's } \\
\text { Service) }\end{array}$ & 4.32 & 4.78 \\
\hline 18 & & 12 & $\begin{array}{l}\text { Doctors are very responsive to patient complaints } \\
\text { (Doctor Services) }\end{array}$ & 4.41 & 4.78 \\
\hline 19 & & 13 & $\begin{array}{l}\text { Nurses behave and behave very friendly in } \\
\text { serving patients (nurse services) }\end{array}$ & 4.37 & 4.78 \\
\hline 20 & & 17 & $\begin{array}{l}\text { Nurses are very skilled in serving (injecting, } \\
\text { measuring tension, etc.) (nurse services) }\end{array}$ & 4.41 & 4.73 \\
\hline 21 & & 21 & $\begin{array}{l}\text { Food is served very timely (food service and } \\
\text { menu) }\end{array}$ & 4.37 & 4.71 \\
\hline 22 & & 23 & $\begin{array}{l}\text { Food is served very clean right (food service and } \\
\text { menu) }\end{array}$ & 4.34 & 4.76 \\
\hline 23 & & 25 & $\begin{array}{l}\text { The availability of medicines at the hospital } \\
\text { pharmacy is very complete (Medical Facilities } \\
\text { and Medicines) }\end{array}$ & 4.29 & 4.78 \\
\hline 24 & & 31 & $\begin{array}{l}\text { The condition of the building and the hospital } \\
\text { environment are very neat, clean and } \\
\text { comfortable }\end{array}$ & 4.34 & 4.8 \\
\hline
\end{tabular}




\begin{tabular}{|c|c|c|c|c|c|}
\hline No & Quadrant & $\begin{array}{l}\text { Atribut } \\
\text { Code }\end{array}$ & Atribut description & $\begin{array}{l}\text { Mean } \\
\text { performance } \\
\text { rating }\end{array}$ & $\begin{array}{l}\text { Mean } \\
\text { importance } \\
\text { rating }\end{array}$ \\
\hline 25 & & 32 & $\begin{array}{l}\text { The location of the hospital is very strategic } \\
\text { (Physical Condition Hospital and Treatment } \\
\text { Room) }\end{array}$ & 4.39 & 4.73 \\
\hline 26 & & 33 & $\begin{array}{l}\text { I feel very safe while being treated at this hospital } \\
\text { (Physical Condition of Hospital and Treatment } \\
\text { Room) }\end{array}$ & 4.44 & 4.71 \\
\hline 27 & & 35 & $\begin{array}{l}\text { Treatment room lighting is very good (RS } \\
\text { Physical Condition and Treatment Room) }\end{array}$ & 4.32 & 4.71 \\
\hline 28 & \multirow{9}{*}{ Quadrant 3} & 3 & $\begin{array}{l}\text { The condition of the waiting place before being } \\
\text { sent to the treatment room is very convenient } \\
\text { (Admission Service) }\end{array}$ & 4.02 & 4.66 \\
\hline 29 & & 15 & $\begin{array}{l}\text { Nurses provide very good responses to patient } \\
\text { complaints (Nurse Services) }\end{array}$ & 4.2 & 4.68 \\
\hline 30 & & 16 & $\begin{array}{l}\text { Nurses are very serious in serving the needs of } \\
\text { patients and personal assistance (bathing, feeding } \\
\text { food, etc.) (Nurse Services) }\end{array}$ & 4.15 & 4.61 \\
\hline 31 & & 19 & $\begin{array}{l}\text { The food menu is very varied (Food Service and } \\
\text { Menu) }\end{array}$ & 4.24 & 4.49 \\
\hline 32 & & 20 & $\begin{array}{l}\text { Food presentation is very well maintained (food } \\
\text { temperature, food freshness, food arrangement) } \\
\text { (Food Service and Menu) }\end{array}$ & 4.2 & 4.54 \\
\hline 33 & & 26 & $\begin{array}{l}\text { Hospital pharmacy services are very friendly } \\
\text { (Medical and Drug Facilities) }\end{array}$ & 4.2 & 4.46 \\
\hline 34 & & 27 & $\begin{array}{l}\text { Time for hospital pharmacy services (Medical } \\
\text { and Drug Facilities) }\end{array}$ & 3.93 & 4.54 \\
\hline 35 & & 30 & $\begin{array}{l}\text { Attitudes and behavior of officers at medical } \\
\text { support facilities are very friendly (Medical } \\
\text { Facilities and Medicines) }\end{array}$ & 4.15 & 4.46 \\
\hline 36 & & 36 & $\begin{array}{l}\text { The treatment room equipment and furnishings } \\
\text { are very complete (Hospital physical condition } \\
\text { and treatment room) }\end{array}$ & 4.15 & 4.66 \\
\hline 37 & \multirow{6}{*}{ Quadrant 4} & 2 & $\begin{array}{l}\text { The service of officers who process entry into the } \\
\text { treatment room is very good (Admission Service) }\end{array}$ & 4.39 & 4.63 \\
\hline 38 & & 7 & $\begin{array}{l}\text { The attitude and behavior of the doctor when the } \\
\text { examination is very friendly (Doctor's Service) }\end{array}$ & 4.59 & 4.59 \\
\hline 39 & & 14 & $\begin{array}{l}\text { Nurse services are very regular every day (pulse } \\
\text { check, body temperature, and the like) (Nurse } \\
\text { Service) }\end{array}$ & 4.32 & 4.59 \\
\hline 40 & & 18 & $\begin{array}{l}\text { The nurse gives a very good explanation of the } \\
\text { actions he will take (Nurse Services) }\end{array}$ & 4.32 & 4.63 \\
\hline 41 & & 22 & $\begin{array}{l}\text { The state of the cutlery is very good (Food } \\
\text { Service and Menu) }\end{array}$ & 4.34 & 4.66 \\
\hline 42 & & 24 & $\begin{array}{l}\text { Behavior of officers who provide very friendly } \\
\text { food (Food Service and Menu) }\end{array}$ & 4.41 & 4.46 \\
\hline \multicolumn{4}{|c|}{ Total Average } & 4.25 & 4.69 \\
\hline
\end{tabular}

The Cartesian diagram is used to see the existence of each statement. The results of the study indicate :

1. Quadrant I (Keep Up the good work)

In this quadrant contains factors that are the high priority in service improvement. It caused the average interest of the respondents is higher than the average perceived performance. From 12 indicators included in quadrant I there are 3 indicators of patient admission services, 2 indicators of medical advice and medication, 2 indicators of the physical condition of the hospital and the treatment room, 5 indicators of administration services.

2. Quadrant II (Concerntrate here)

Quadrant II, consists of factors that must be maintained quality because in this quadrant the average performance perceived by customers and the interests of patients is high. 15 indicators in quadrant II, the indicator are patient admission services, 5 indicators of doctor services, 2 indicators of nurse services, 2 indicators of food service and 
menus, 5 indicators of services in the physical condition of hospitals and treatment rooms. From 15 indicators ini Malahayati expected to continue to maintain performance and improve its performance because the indicators in this quadrant are in apropriate with patient expectations.

3. Quadrant III (Low Priority)

Quadrant III contains factors that have a low degree of importance and performance. That is the quality of services provided is low but respondents also consider these aspects to be less important. There are 9 indicators included in quadrant III consisting of 1 indicator from patient admission service, 2 indicators from nurse service, 2 indicators from food service and menus, 3 indicators from medical advice and medicines, 1 indicator from service to physical condition of hospital and room care.

4. Quadrant IV (Possible Overkill)

Quadrant IV contains factors that are judged to show excessive results, meaning that for these factors the respondent considers it not important, but in reality the services provided are well done and exceed the expectations of the respondents. There are six indicators included in quadrant IV consisting of 1 indicator from patient admission service, 1 indicator from doctor service, 2 indicators from nurse service, 2 indicators from food service and menu.

\section{Discussion}

Admission services are the beginning of all service activities. The average patient's perception of this service is 4.19 in the range $3.41-4.2$, which means it has good value.there are three indicators of Admission service in quadrant I and 3 others spread in other quadrants. Indicator in Quadrant I repairs must be made, namely service before being sent to the treatment room very quickly, service time in the emergency room and emergency room have very complete equipment. Improvements that can be made by increasing the speed of service in carrying out actions against emergency patients according to the SOP and the standard of service time, add medical personnel, add the necessary equipment according to the needs of the emergency department.

The average patient's perception of the doctor's service is 4.47 in the range of $4.21-5$ which means it has best value. Five indicators of physician services are in quadrant II which shows that the patient is satisfied with the service of the doctor at Malahayati hospital so that efforts are needed to maintain performance and maintain the quality of services.

The average patient's perception of nurse services is 4.29 in the range of 4,21 - 5, which means it has best value. Two indicators on nurse services are in quadrant II, namely the attitude and behavior of nurses is very friendly and highly skilled nurses must maintain their quality. Other indicators spread in quadrant III and quadrant IV.

The average patient's perception of food service and menu service is 4.31 in the range of $4.21-5$, which means it has very good value. Two indicators for this service are in quadrant II, the other indicators spread in quadrant III and quadrant IV. The average patient's perception of medical services and drugs is 4.16 in the range of $3.41-4.19$, which means it has good value. Indicators of medical equipment in hospitals and rs laboratory services, including medical facilities and medicines. These two indicators can be improved by planning the needs of medical equipment and increasing laboratory services based on the growth in the number of patients.

The average patient's perception of the hospital's physical condition and treatment room is 4.24 in the range of 4.21 - 5 which means very good. Indicators of the physical condition of the neat, clean and comfortable treatment room have not been fulfilled the patient's expectations in this case bathroom dirty . In the indicator of insect-free treatment room (ants, flies, mosquitoes) an indicator that must be a top priority in making improvements because this indicator has a value of conformity level of $80.93 \%$ and is the lowest of the 42 other indicators. What can be done to overcome these two problems is to conduct periodic and thorough cleaning, the addition of cleaning staff and the addition of cleaning schedules in each treatment room to maintain the cleanliness of the hospital environment and the comfort of patients. Improving the supervision system, controlling the cleaning service unit.

The average patient's perception of Administrative Services Out of Hospital is 4.06 in the range of 3.41 - 4.2, which means it has good value. All indicators of the Administrative Services Out of Hospital service are in quadrant I. Patients consider that the performance of this service is not maximal and is not yet in line with the expectations of patients. Therefor, hospital needs to make changes to this service namely changes in administrative procedures to make it simpler and to use hospital management information systems, provide training to Administrative Service officers in order to improve communication techniques so that they can provide better explanations and patient easy to understand, improve friendly attitude and behavior in providing services to patients. Addition of financial officers or cashiers if needed, establish SOPs about standard service times at the time of payment to shorten service time.

\section{Conclusion}

The level of conformity shows the level of importance is higher than the level of performance with a value of $90.62 \%$ which means that inpatients are not satisfied with the services of Malahayati Hospital and indicator 
hospital that must be improved in quadrant I are patient admission services, medical and medicinal facilities, the physical condition of the hospital and the treatment room, and administration Services.

\section{Reference}

Herlambang, Susatyo. 2016. Healthcare Hospital Management. Gosyen Publishing. Yogyakarta

Kotler, Philip dan Kevin Lane Keller. 2009. Marketing Management. Erlangga. Jakarta.

Lovelock, Wirtz . 2011. Services Marketing People, Technology, Strategy. : Indonesian Perspective 1, Ed.7. Erlangga. Jakarta.

Marpaung, Marvin Daulat. 2016. Analysis of the Effect of Service Quality on Inpatient Satisfaction at RSUP. H. Adam Malik Medan. Thesis. Program Study Magister Manajemen. USU

Muninjaya, I Gde. 2011. Healthcare Management. EGC. Jakarta

Nursalam. 2016. Nursing Management: Application and Practice of Professional Nursing, 2rd Edition. Jakarta: Salemba Medika

Payne, Adrian. 2007. The Essence of Service Marketing. Salemba Empat. Jakarta.

Sinulingga, Sukaria. 2015, Research methods. 3rd Edition. USU Press. Medan.

Suryawati, C, Dharminto, Shaluhiyah, Z. 2006. Compilation of Hospital Patient Satisfaction Indicators in Centre Java Provinces. Health Service Management Journal. 09 (04) : 177 - 184

Tjiptono, Fandy dan Gregorius Chandra. 2011. Service, Quality \& Satisfaction

$3^{\text {rd }}$ edition .Andi Offset. Yogyakarta

Tjiptono, Fandy. 2015. Marketing Strategic. Andi Offset. Yogyakarta.

Zeithaml, V.A. and M.J. Bitner. 2009. Service Marketing : Integrating Customer Focus Across the Firm. McGrawHill. Boston

Zahara Meutia, I was born in Medan on March 6, 1989. I graduated in 2017, Program Study of Magister Management, University of Sumatera Utara, Medan, Indonesia. 